\title{
STUDENTS' COLLABORATIVE STORY WRITING PROJECT IN AN EXTENSIVE READING PROGRAM
}

\author{
Anita Kurniawati Hadiyanto \\ (anita.hadiyanto@uksw.edu) \\ Universitas Kristen Satya Wacana \\ Jl. Diponegoro No. 52-60, Salatiga, Central Java, Indonesia
}

\begin{abstract}
As the nature of Extensive Reading (ER) emphasizes the reading activity, most ER follow up activities are developed to support the act of reading. This might neglect the fact that reading can also be a stimulus for creative and imaginative writing. Although ER has a potential role to develop students' L2 writing, not many have explored it. This preliminary study investigates a writing project undertaken as a post-ER activity. This project was done at the end of an ER program in an EFL context. In this project, the students worked collaboratively to write a 1,000 -word short story. The study examined how the ER teachers and ER students in the study perceived the story writing project. Data were gathered from semi-structured interviews with three ER teachers and six ER students. Findings showed that both the teachers and students perceived the story writing project as beneficial to enhance the students' creativity and imagination. They also agreed on the connection between reading and writing. The quality of the story was perceived to be significantly influenced by the students' reading behaviors. Practical suggestions on how to integrate this project into an ER program were also offered.
\end{abstract}

Keywords: extensive reading, collaborative project, story writing

DOI: http://dx.doi.org/10.15639/teflinjournal.v30i2/197-211

Extensive reading (ER) is an approach to teaching reading which aims to introduce the joy of reading to language learners. In ER, the students learn to read by reading a large number of easy and enjoyable materials for real-world reading purposes. Day and Bamford $(1998,2002)$ introduced ten ER principles which, as Macalister (2010) claimed, have influenced ER practices since then. 
According to these principles, the students can choose their own books based on their interest and linguistic ability. They can stop reading when they find the book too hard or when they do not find it interesting. As personal preferences are involved in the students' reading behavior, the reading speed tends to be faster rather than slower. Moreover, the students read for pleasure, information, and general understanding rather than for academic purposes. The follow-up ER activities aim to support the act of reading rather than to assess the students' reading performance.

The ER approach has attracted increasing attention from L2 scholars in the past few decades. Studies convincingly show the benefits of ER in improving various aspects of L2 learning such as increased reading proficiency and reading rate (e.g. Beglar \& Hunt, 2014; Elley, 1991; Robb \& Susser, 1989), enriching vocabulary (e.g. Horst, 2005), and improved writing proficiency (e.g. Hafiz \& Tudor, 1989; Mason \& Krashen, 1997). Maley (2005, p. 354) even claimed that ER is "the single most effective way to improve language proficiency." ER has also been reported to have a positive influence on students' reading attitudes and motivation (e.g. Ro, 2013; Yamashita, 2013). Despite the beneficial effects of ER, one cannot forget the fact that not all ER projects produce positive results. The Hong Kong Extensive Reading Scheme in English (HKERS) was an example of this (Green, 2005).

Commenting on the disappointing results of the HKERS, Green (2005) pointed out that the nature of reading in ER which is individual and silent fails to provide a clear and direct purpose for reading. Moreover, promoting the idea that learners should see reading as an intrinsically rewarding activity may not satisfy learners who value more short term learning goals. To obtain maximum benefits, he suggested that ER has to be integrated with other language learning activities so that the learners can perceive the purpose of the ER activities more clearly. Agreeing with Green, Day and Bamford (1998) suggested that it is necessary to build a classroom environment supportive of reading. The learners need to be involved in the activities that can make them engage in reading. They also need to interact with both the teacher and other learners to experience reading as a valuable, exciting, pleasurable, and worthwhile activity. Day et al. (2015) emphasized that follow-up ER activities should demonstrate that learning to read can be purposeful and enjoyable. He also mentioned that these activities help the students develop other skills in English.

Bamford and Day (2004) published Extensive Reading Activities for Teaching Language which provided over 100 ER activities. These activities 
aim not only to increase students' enjoyment of reading, but also to link reading with particular aspects of language learning such as increasing oral proficiency, improving reading and writing skills, or learning new vocabulary. These activities, according to Stoller and Holliday (2005), could help teachers exploit the students' language learning potential. To support the individual reading activities, the students, for example, can share the books they have read, write a different ending, write a letter to the character in the story, and even perform a mini-drama. These activities can help improve not only the students' reading ability but also their speaking and writing ability. Chen (2018) found that the after reading tasks which are meaningful and interactive, such as opinion exchange or decision-making tasks, and which have clear outcomes, promote language development, engage students in meaningful interaction, and motivate them to keep reading and develop reading habits.

As the nature of the ER approach emphasizes reading, it is not surprising to find that many ER follow-up activities have been developed to support the act of reading. Jacobs and Renandya (2015) also suggest some follow-up activities to accompany the individual reading such as giving a review of the book to convince others to read or not to read it, designing a bookmark to suit the book, designing a poster to advertise the book, and writing a newspaper article about the event, characters, or information in the book. In Bamford and Day (2004), some of the follow-up ER activities involve students doing some creative and imaginative writing. Although the so-called "ER in reverse" activities require less reading than most of the other activities do, these activities could not be separated from the reading the students have done. Stoller and Holliday (2005) asserted that these activities seem to run counter to the ER principle which states that an ER program requires a great deal of reading. Maley (2005), however, viewed these "as a springboard for something else" (p. 355). Regardless of the different opinions, it is still beneficial to implement this "ER in reverse" activity.

In the Once Upon a Time activity contributed by Claire Hitosugi (in Bamford \& Day, 2004), for example, the students have to use words from the books they are reading to write their own stories. In My Own Story, contributed by Anne Burns (in Bamford \& Day, 2004), the students write stories for their peers to read. They work in groups, tell their personal experience and write their story. These activities seem to resemble traditional writing tasks in which the students draft essays, peer edit and revise their own written work rather than do other reading activities. Nevertheless, the students may not be able to 
write well if they read only a little. Numerous studies have shown that there is a connection between reading and writing (Ahmed, Wagner \& Lopez, 2014; Olson, 2011; Zhang, 2018). Hitosugi (in Bamford \& Day, 2004, p. 163) wrote that "Students feel more comfortable writing if they use words they were previously exposed to in their reading". Both Hitogusi and Burns also implicitly mentioned using the students' written production as a source of ER materials in their activities. This confirms Day and Bamford's (1998) idea about the possibility of having learners' self-created stories as ER material.

Green (2005) further pointed out that since the reading material selection was one of the reasons for the failure of HKERS, he also suggested the use of learners' self-created writing. He admitted that students' self-created material cannot be the only source of reading input. Nevertheless, this material can still be remarkably valuable as the writers gain an audience as they can interact directly with their readers. For the readers, reading their friends' writing can also be inspiring. Quoting the work of several researchers, Zhang (2018) concluded that reading and writing instruction can benefit each other. In other words, reading instruction can enhance writing and writing instruction can help improve reading performance. Even though early findings on the potential role of ER in L2 writing development are encouraging, Park (2016) admitted that the research on the impact of ER on writing skills is relatively small. His research in this area is among the few studies that examined the impact of ER on writing in an EAP context.

This preliminary study was conducted to investigate the implementation of a collaborative story writing project at the end of an ER program in an EFL context. The project was given to the ER students after they had read a certain amount of graded reader books. Hirvela (1999) pointed out that as writing is a social process, students need to work with their peers to function simultaneously as writers and audience members within authentic communicative contexts. It was expected that our ER students would not only help each other to write their own stories, but also could experience how to function simultaneously as both writers and readers. Two research questions guided this study. The first examined how the ER teachers perceived this collaborative story writing project and the second explored how the ER students perceived this story writing project. It is hoped that this preliminary investigation can provide a contribution to uncovering the role of ER in L2 writing and to the possibility of having learners' self-created material for an ER program. 


\section{METHOD}

The study was conducted in an undergraduate English teacher preparation program in Indonesia. ER is a required four-credit hour course offered to firstyear students. This course aims at developing better reading habits through the joy of reading. To reach this aim, the students were required to read 1,250 pages of graded readers available in the university's library. Students were encouraged to read in and out of the classroom at their own pace and level.

The class met twice a week for two hours. The first two weeks of the course were used to help the students check their reading levels, find appropriate books, and monitor and evaluate their reading progress. For the next ten weeks, the class meetings were used for the students to share, discuss and report what they had read. They also did project presentations both individually and in a group. The collaborative story writing project was given on Week 12, three weeks before the semester ended. All the class activities in this course were adapted from Extensive Reading Activities for Teaching Language (Bamford \& Day, 2004).

The course assessments consisted of the students' individual reading performance, three individual projects, and two group projects. The individual reading performance was assessed based on the number of pages the students had read and their reading reports. The reading reports had to be submitted for each graded reader the students had read for that particular week. The three individual projects were mostly presentation activities. The students were asked to present their favorite quotation, to find appropriate gifts for the characters, and to promote their favorite books. The two group projects were (1) performing a role-play and (2) writing their own stories based on the books the students had read.

To start the collaborative story writing project, the students had to list at least five new words from the books they read in week 12. They then shared and discussed the meaning of their vocabulary word lists in class. The students worked in a group of three and chose only ten words from their word lists. It was expected that the chosen word lists could help the students build their imagination for a one-paragraph story they were going to write in a group. It was also expected that the students would become more familiar with those new words. After the students finished writing their paragraphs, they had to share it with their friends from another group to get feedback. The students' one-paragraph story writing would then be used as a stepping stone for 
developing their one-thousand-word long story. The ER teachers helped to monitor the progress of the story writing project through group consultations.

This study involved three ER teachers and six ER students. The teachers were all Indonesian females, and they had taught ER since 2013. Each of these teachers was in charge of an ER class with 20 students. The six ER students were the representative members who were randomly selected from six different groups in one ER class. There were two male and four female students. Their ages were between seventeen to eighteen years.

This study used semi-structured interviews. The interview with the ER teachers was used to explore their perceptions toward the story writing project in the ER program. There were five main questions and some supplementary questions, depending on their answers to the main questions. The interview with the students was used to explore the students' perceptions toward the collaborative story writing project. The students' story drafts, both the first and final draft, were also used to explore their writing experience and to what extent the reading helped them do the project. There were six main questions and some supplementary questions, depending on their answers to the main questions.

The data were analyzed qualitatively. The participants' responses were grouped thematically according to how they perceived the collaborative story writing project in an ER class. For the teachers, this included how their students responded to this project and the challenges they had to deal with. For the students, this included their feelings toward the project, the difficulties they faced and the additional point(s) they could get from the project. It was then followed by identifying relevant points, common patterns, and divergence in the participants' perceptions of the collaborative writing projects.

\section{FINDINGS AND DISCUSSION}

The discussion here will be divided into two sections. The teachers' interview results will first be explored, followed by the students' interview results.

\section{Teachers' Perceptions}

Different from academic papers which are written following rigid academic discourse, story writing requires creativity and imagination. The 
writer needs to be able to use their imagination to develop characters, setting, plots and other elements of a story. Teacher B and Teacher C pointed out that the story writing project in the ER class was beneficial for enhancing the students' creativity and imagination. These are their comments:

This project gives a chance for the students to develop their creativity. From the books they have read, they could write their own story. (Teacher B)

This project is exciting and easy as well. The students can develop their imagination. They can learn how to write their own story. So, in an ER class, the students do not only read books, but they also can learn to write their own story. The students received a lot of input from the books they have read. This story writing project can help us check whether the students' vocabulary has improved or not. (Teacher C)

From Teacher C's statement, it could be inferred that she responded positively to the writing project in the ER class. Her statement also supports Bamford and Day's (2004) idea that reading in the ER class can be used as a stimulus for creative and imaginative writing as well. Moreover, she views this story writing project as a potential tool to measure students' vocabulary mastery at the end of the ER program. It is well noted that reading in ER is its own reward. This story writing project, in this case, helps to demonstrate the reward the students gain from the reading they have experienced throughout the program.

In addition to the positive views toward the story writing project, the teachers also thought that reading seems to be nicely connected to writing. Teacher B and Teacher C, for example, found that some students in their classes did not read well their graded reader books, and this affected the quality of their writing, as shown in the excerpts below:

Many of my students did not read all the chapters in the [graded reader] book. They read only the beginning and the ending of the story. I found that this influenced their drafts. They could write only the introduction and the ending. There is no climax and resolution. (Teacher B)

My students focused more on understanding the general idea of a story. They didn't pay attention to the details. It seems that their primary goal was only to be able to write book reports. This made them less aware of the plots. No wonder that their stories were not good enough. Last year students were better than this year. (Teacher C) 
Zhang (2018) mentioned that reading and writing are dependent on similar cognitive skills and processes. These provide simultaneous growth as well as a transfer of knowledge. As the students in Teacher B's class only read the first and the last few pages of their selected graded reader books, they can only notice and model the beginning and the ending of a story when they are writing their own story. This is similar to some of the students in Teacher C's class whose reading purpose was more to complete their reading reports than enjoying and being engaged in the graded reader stories. This made them not aware of good story writing.

Zhang (2018) concluded that there are four knowledge bases shared by reading and writing: content or domain knowledge, metaknowledge, knowledge of text attributes, and procedural knowledge. Teacher A's and Teacher B's experience with their good student readers illustrate this point.

For the students who love reading, they will have many ideas. They can have a good imagination. And they can write their story well enough. Although not all groups could write a good story, their drafts had all the components of a story. A group tried to write an open ending story, but they were not successful. But there was another group that could write a very good ending. (Teacher A)

There was a group. The members usually read about a love story. But for this project, I don't know why they wanted to write a murder mystery. The result was not good. Probably it was because they never read stories about murder. This made them missed many details of the story. (Teacher B)

From the two teachers' statements, it could be seen how the content or domain knowledge and metaknowledge are transferred. When the students are fully engaged in the story, they will enjoy reading about the settings, the events or the characters that the writers write about. This will then help them when they write their own story. They know all the components for a good piece of story writing. They know how to engage and satisfy readers.

When asked about the possibilities of having the students' self-created stories as a source of ER materials, the teachers seemed to embrace the idea (see excerpts below). Materials are "the heart and soul" (Day et al., 2015, p. 16) for a successful ER program. While language learner literature or graded readers has become ER teachers' and practitioners' favorite ER materials, as Green (2005) noted, students' self-created materials can be potential additional ER materials as well. 
We can use the students' story for the next ER class regardless of the quality of the story. The next ER students can read the draft in addition to the graded readers. We can talk about the draft, the strengths, and weaknesses of the draft. (Teacher C)

It will be good if we can compile the students' story and make a book. We can put it in our library so that other students can read them. This will make the student writers proud. They know that their story will be read by other students as well (Teacher A)

Reading and writing have been traditionally taught as two separate subjects. However, numerous studies have shown that reading and writing are connected; they are two sides of the same coin, so to speak. Instruction that integrates reading and writing should make more sense and can be very beneficial for students' literacy development (Grabe \& Zhang, 2013; Vandrick, 2018; Zhang, 2018). Although the ER approach gives more emphasis on reading than writing activities, Bamford and Day (2004) have provided a platform for integrating reading and writing in an ER program through the socalled "ER in reverse" activities. While Day and Bamford (1998) aimed to build a community of readers, they might also build a community of writers at the same time. Teacher B's statement illustrates this point.

Peer reviewing is good for the follow-up activity after the students finish writing their story draft. They can exchange their draft with their friends. They could do peer review, identify the strengths and weaknesses, and give suggestions on how to improve it. It is good to do it with their classmates because by reading their classmate's drafts, they could reflect their own story draft. (Teacher B)

\section{Students' Perceptions}

The students' interview data showed that all of them had similar perceptions about this story writing project. They all agreed that this project was exciting as it gave them a chance to write their own story. To all of them, being able to play with their imaginations and to combine their idea with their friends' idea became the most exciting yet challenging point. Hirvela (1999) stated that by doing collaborative writing, the students engaged directly and productively in a dialogue with their peers. The students had to listen to ideas from their friends, to negotiate their own ideas, to accept suggestions and to decide which ideas are appropriate for their group story. Statements from Student F and Student D illustrate this point: 
This project was exciting because I could discuss and even argue about the plot with my friend, AL. He also gave many suggestions for my idea and kept on reminding me not to write our story plot like Indonesian soap operas. (Student F)

When we discussed the character and settings. At first, I wanted the character of the butler to be a young man. But, SF said that it is better if the butler was an old person. We can play more with the readers' emotion. I think she is right, so I take that suggestion. And then about the setting. I think the waterfall setting with the cave is too mainstream for a story about a treasure. The treasure is usually found in the cave behind the waterfall. But my friend said this is only a short story. It is better if we can have common things. (Student D)

The story writing project cannot be separated from the individual reading that the students have done previously. The students explicitly mentioned that the stories they have read inspired their writing.

The inspiration came from several stories. I read Amistad, and I wanted to take the idea from that story. I discuss this with my friend. She also shared the good books she had read. And we discussed the possibility of integrating the story idea into our own story. (Student C)

I got inspiration from Jane Eyre. I wanted the character in my story looked like her, young and tough. Then I read a story about a butler who loved his work very much. The title is "The Remains of the Day" if I'm not mistaken. Unfortunately, the ending was sad. I don't want my story to have a sad ending. I wanted to create a happy ending story. (Student D)

All the students agreed that reading and writing should be integrated. They claimed that the reading they did helped them finish their story writing project. They could model how the writers write the plots, create the problems and end the story, and also learn how to play with lexical and syntactical structures to write a good story. These are their statements:

The reading activity helped me do this project. By reading a lot of books, we know various plots. We know how to make a good plot. Besides, the reading also enriches our vocabulary. I learned about the use of conjunctions. First, I don't know that the word 'thus' can be used in a novel. Then I found that the word "thus" was used in one of the stories I read. So, I used it in my story. Also, the expression "had taken a toll on his body", I got that phrase from one of the books. (Student D) 
I think the reading helped because we could know how to create anticlimax and resolution. We could create interesting problems. We also know how to use appropriate words. From level 4 and above, I could get many vocabularies. (Student E)

I could learn how to make sentences from the reading. I also learn how to connect one scene with another one so that the story can flow smoothly enough. (Student A)

I used some swearing words for the dialogue between Tom and his friend, Johnny, because I wanted to show their relationship. It is common for buddies to speak that way; more casual I think. I learn it from some novels I read before. It seems that those phrases were planted in my head, and when I wrote, those phrases suddenly came out. (Student B)

From these four statements, it can be seen that the students experienced the transfer of content knowledge and knowledge about text attributes (Zhang, 2018) from the books they had read to the story they were writing. In the statements from Student D, Student E and Student A, it can be seen that the transfer of content knowledge took place. From Student B's explanation, knowledge about text attributes can also be noticed. Student B modeled the writer's writing style when she wrote the dialogue between the characters in her story. She was aware that the words she had chosen can strengthen the description of the characters. Student D's experience confirmed the findings of the benefits of ER in enriching vocabulary. She, in this case, was not only aware of the use of conjunctions or the phrases, but she also used them when writing her own story. Besides the students' experience in knowledge transfer between reading and writing, Student A also explicitly claimed that reading was an essential aspect of being able to write well.

I tried to write a fanfiction before this class. But then I stopped in the middle because I didn't know how to continue the story. I rarely read books before. If we don't read books, it will be difficult to write because we don't know what to write. (Student A)

Another evidence on how reading is connected to writing is through Student C's and Student D's experience. When they re-read their own story again, they could identify the weaknesses of their own stories. 
208 TEFLIN Journal, Volume 30, Number 2, July 2019

This part, when the main character met the old woman. It is suddenly mentioned that the old woman was a witch and she is the main character's aunt. We haven't explained anything, but then suddenly the old woman became the witch and Alexandria's aunt. (Student C)

I realized that the characteristics of the master are still unclear. We should write more about him. And the ending of the story too. It's like the story only ends that way. (Student D)

Statements from Student C and Student D show the involvement of metaknowledge in reading and writing (Vandrick, 2018; Zhang, 2018). From the individual reading they had done, they could learn unconsciously about how to build a good story, how to maintain the flow of the story, how to relate one conflict with others. When they re-read their story, they could have more awareness of what was missing from their own story.

Exploring the possibilities of having other students read the students' selfcreated stories, all the ER students here viewed this idea positively. They mentioned several reasons for these positive views, such as they want to share the moral value of the story or to inspire their juniors.

It's better to compile our stories and put them in the library so that others can also read this story. When we wrote this story, we really thought the moral value we could share from this story. We chose what is valuable for a person is not always valuable for another person. I think this is good to share with others. (Student D)

It might be embarrassing if our story is read by others. We might have grammatical mistakes or incorrect spelling. But I think we can inspire our junior. If we can write a short story, why can they do the same? (Student E)

\section{CONCLUSIONS}

Overall, the findings show that both the teachers and students have the same perceptions of the collaborative story writing project in an ER program. For the teachers, this project is beneficial for enhancing the students' creativity and imagination. Moreover, the reward of individual reading can also be demonstrated through the students' stories as the product of this activity. All the teachers agreed on the connection between reading and writing. They believe that students' reading behavior has a significant influence on the quality of their writing. 
For the students, this collaborative story writing project was also exciting. They enjoyed discussing their story ideas and combining the ideas from all the group members. The ER students also noticed that what they learn from reading the books helped them write their own story. They followed the plot or the conflict of certain stories, they used the vocabulary they learned from the stories they read, and they even modeled the author's writing style,

Although the findings of this study may only be applicable in this particular context, the results are worth considering. With the potential value of ER to story writing, it is worth giving more room for this activity in an ER program. This collaborative story writing project can be offered at the end of an ER program if the students have read many storybooks. Although the ER approach emphasizes reading rather than writing activities, there should be activities that can help students become aware of the essential story writing components. Hence, a teacher's guide is still necessary. It could be in the form of introducing an example story and discussing the elements such as setting, characters, conflicts, and resolution. It would also be good if the teachers can provide consultation sessions. With this story as the product of an ER program, the students can see more clearly that ER improves their reading and writing skills.

\section{REFERENCES}

Ahmed, Y., Wagner, R. K., \& Lopez, D. (2014). Developmental relations between reading and writing at the word, sentence, and text levels: A latent change score analysis. Journal of Educational Psychology, 106(2), 419-34.

Bamford, J., \& Day, R. (eds). (2004). Extensive reading activities for teaching language. Cambridge: Cambridge University Press.

Beglar, D., \& Hunt, A. (2014). Pleasure reading and reading rate gains. Reading in a Foreign Language, 26(1), 29-48.

Day, R., Bassett, J., Bowler, B., Parminter, S., Bullard, N., Furr, M., Prentice, N., Mahmood, M., Steward, D., \& Robb, T. (2015). Extensive reading, Revised edition - Into the classroom. Oxford: Oxford University Press.

Day, R., \& Bamford, J. (2002). Top ten principles for teaching extensive reading. Reading in a Foreign Language, 14(2), 136-141.

Day, R., \& Bamford, J. (1998). Extensive reading in the second language classroom. Cambridge: Cambridge University Press. 
Elley, W. B. (1991). Acquiring literacy in a second language: The effect of book-based program. Language Learning, 41(3), 375-411.

Grabe, W., \& Zhang, C. (2013). Reading and writing together: A critical component of English for academic purposes teaching and learning. TESOL Journal, 4(1), 9-24.

Green, C. (2005). Integrating extensive reading in the task-based curriculum. ELT Journal, 59(4), 306-311.

Hafiz, F. M., \& Tudor, I. (1989). Extensive reading and the development of language skills. ELT Journal, 43(1), 31-42.

Hirvela, A. (1999). Collaborative writing instruction and communities of readers and writers. TESOL Journal, 8(2), 7-12.

Horst, M. (2005). Learning L2 vocabulary through extensive reading: A measurement study. The Canadian Modern Language Review, 61, 355-382.

Jacobs, G. M., \& Renandya, W.A. (2015). Making extensive reading even more student-centered. Indonesian Journal of Applied Linguistics, 4(2), 102-112.

Macalister, J. (2010). Investigating teacher attitudes to extensive reading practices in higher education: Why isn't everyone doing it? RELC Journal, 41(1), 59-75.

Maley, A. (2005). Extensive reading activities for language teaching. ELT Journal, 59(4), 354-355.

Mason, B., \& Krashen, S. D. (1997). Extensive reading in English as a foreign language. System, 25, 91-102.

Olson, C. B. (2011). The reading and writing connection: Strategies for teaching and learning in the secondary classroom. Boston, MA: Pearson.

Park, J. (2016). Integrating reading and writing through extensive reading. ELT Journal, 70(3), 287-295.

Chen, I.-C. (2018). Incorporating task-based learning in an extensive reading programme. ELT Journal, 72(4), 405-414.

Robb, T. N., \& Susser, B. (1989), Extensive reading vs. skills building in an EFL context. Reading in a Foreign Language, 5(2), 239-251.

Ro, E. (2013). A case study of extensive reading with an unmotivated L2 reader. Reading in a Foreign Language, 25(2), 213-233.

Stoller, F. L., \& Holliday, A. (2005). Extensive reading activities for teaching language. TESOL Quarterly, 39(2), 351-353.

Vandrick, S. (2018). Reading and writing connections in writing about literature. The TESOL Encyclopedia of English Language Teaching, 1-6. 
Hadiyanto, Students' Collaborative Story Writing Project 211

Yamashita, J. (2013). Effects of extensive reading on reading attitudes in a foreign language. Reading in a Foreign Language, 25(2), 248-263.

Zhang, L. (2018). Reading and writing connections. The TESOL Encyclopedia of English Language Teaching, 1-5. 